\title{
射出成形機型締装置の異常検知
}

長沼 恒雄 ${ }^{*} 1, * 2$, 橋本 浩一*1

\section{Anomaly detection of the injection molding clamping unit}

\author{
Tsuneo NAGANUMA ${ }^{* 1,22}$ and Koichi HASHIMOTO*1 \\ ${ }^{* 1}$ Graduate School of Information Science, Tohoku University \\ 6-6-01 Aramaki Aza Aoba, Aoba-ku, Sendai-shi, Miyagi 980-8579, Japan \\ ${ }^{* 2}$ Aska company \\ 4004 Koutaka, Kato-shi, Hyogo 679-0221, Japan
}

\section{Received: 7 June 2018; Revised: 9 December 2018; Accepted: 1 March 2019}

\begin{abstract}
Our previous research (Naganuma, Hashimoto, 2018) demonstrates that the anomaly detection in the injection molding clamping unit will be made possible by evaluating the operating mode. Based on our previous research, this article suggests the sign of failure in the injection molding clamping unit can detected the anomaly detection through the unusual values of the production machine. A plastic injection molding manufacturing company built a data network system that collects a machine state $\log$ in the factory and saves data in the server. Over the past two years, two failures of clamping unit in the injection molding machine occurred under the production and the machine data of both cases are logged. We use a threshold method to detect the anomaly of the clamping unit. This thresholding is obtained by the maximum accuracy of the confusion matrix. It was tested against the two failure cases, which number of data is about 1.8 million cycle data. As a result, we discovered that this threshold method can detect the anomaly for both cases before the machine has to be shut down by the failure. Thus, it is expected to be useful for the preventive maintenance and the quality assurance of products due to its ability to detect the sign of failure in the injection molding machine.
\end{abstract}

Keywords : Injection molding, Big data, Clamping force, Threshold, Machine failure, Anomaly detection

\section{1. 緒言}

現在, 日本において進行している第 4 次産業革命は, いくつかの技術革新がコアとなっている. 一つ目は IoT 及びビッグデータである. 工場の機械の稼働状況から，交通，気象，個人の健康状況まで様々な情報をデータ化 し，それらをネットワークでつなぎ，これを解析・利用することで新たな価值が生まれている。二つ目はAI であ る. 人間がコンピュータに対してあらかじめ分析上注目すべき要素をすべて与えなくとも，コンピュータが自ら 学習し，一定の判断を行うことが可能となっている (内閣府, 2017).このような IoT, AI などのデジタル技術は, 製造業において異常や異変，リスクの検知などの「予知保全」や「遠隔保守」，さらにはデジタル的な「技術継承」 などを可能にする（経済産業省，2017）。また，機械等の故障は突発的に発生するものではなく，その前兆として 異常があるため，異常の検知は故障を防止する基本的かつ有効な手段になると考えられている（高橋，2003）.

プラスチック製品製造会社の A 社においても，工場内にある成形機を社内ネットワークに接続し，リアルタ イムで成形機の型締力, 射出圧力, シリンダー温度などの各種データを収集し, 蓄積している. それらのデータ

\footnotetext{
No.18-00258 [DOI:10.1299/transjsme.18-00258], J-STAGE Advance Publication date : 8 March, 2019

*1 正員, 東北大学 大学院情報科学研究科（干980-8579 宮城県仙台市青葉区荒巻字青葉 6-6-01）

*2 アスカカンパニー (株) (广679-0221 兵庫県加東市河高 4004)

E-mail of corresponding author: tsuneo-naganuma@askacompany.co.jp
} 
収集の主目的は成形機内で起こる異常を検知し，予知保全や品質保証に役立てることにある。しかし，A社では これらのデータを活用した成形機の予知保全が出来ていないため, 故障してから成形機メーカーの保守担当者に 修理を依頼するケースが多い，一方，成形機メーカーにおいてもボールネジの故障予知に AI を活用する実証実 験が行われているが（日本電気株式会社，2018），現状では市場に投入されていない.

そのような状況の中， 2017 年 2 月から 2018 年 3 月の間に，A 社の同じ型の成形機において生産中に型締装置 の故障が 2 回発生した．故障事例 1 は型締用ボールネジに損傷が見つかり，ボールネジアッセンブリ一式の交換 が行われた. 故障事例 2 は型締トグル機構のアームの割れが発生し，アーム一式の部品交換が行われたそし て，それらの故障の発生前後における生産中の型締力データがすべて A 社のサーバー内に保管されている.

これらについて, 実際の生産時に発生した故障データを使って, 筆者らが提案した推定手法（長沼, 橋本, 2018）で用いた混同行列により，異常の検知が可能であったことが判明した．本論文ではその事例について報告 する.

\section{2. 運転モードの混同行列と異常検知}

成形加工は，型締一射出一保圧一冷却一型開一製品取り出しを繰り返す一連のプロセスであり，この 1 回のプ ロセスを 1 サイクルと呼ぶ. 成形機の運転モードには「全自動モード」と「半自動モード」の 2 種類があり，全 自動モードは人手を介さずに連続的に高速で製品を生産するモードであり,トラブル等のない通常の生産である. 半自動モードは作業員が介入しつつ製造過程をチェックしながら 1 サイクルごとに生産するモードであり，生産 開始や終了時の調整作業，後工程や成形機内部でのトラブルなどからの復帰の時に用いる．全自動モードでは成 形サイクルが一定のため, 型締装置の熱平衡が保たれ, 型締力変化は安定している. 一方, 半自動モードでは成 形機停止時間がばらつき, 熱平衡が不安定になり, 型締力変化が大きくなる.また, 全自動モード中に型締力が 起因と推定される前兆 (製品不良, 異音など) が発見されると, 作業者が半自動モードで所定の保守作業を行い, 異常がなければ保守作業で型締力変化は安定するが, 異常があれば型締力変化は不安定な状態のままで推移する.

筆者らは以前に，型締力の平滑化を行った後，サイクルごとの型締力変化率を算出し，混同行列を使用し，闇 值を設定することにより, 運転モード (全自動運転と半自動運転)を推定することを提案した (長沼, 橋本, 2018). 今回は，その時に考案した $2 つ の$ 運転モードにおける混同行列を用いて最適化する閾值を検討すれば，成形機の 型締装置の異常検知も可能ではないかと考えた. まず本章ではその型締力, 混同行列と閾値について説明する. なお，型締力とは充てん時の成形材料の圧力に抵抗して，金型を閉じておくために金型に加える力である（JIS B $8650,2006)$.

\section{$2 \cdot 1$ 型締力平滑化と変化率}

成形機の型締力センサーデータに重畳するノイズを除去するために平滑化フィルターを用い，平滑化後の型締 力変化率を算出する. 平滑化フィルターとしては, Binomial Filter を使い, その平滑化されたデータを $\boldsymbol{Y}_{t}$ で表

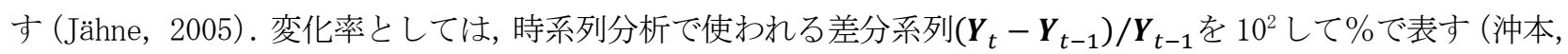
2016).

$$
\begin{aligned}
A & =\left[\begin{array}{lllll}
1 / 16 & 4 / 16 & 6 / 16 & 4 / 16 & 1 / 16
\end{array}\right] \\
\boldsymbol{X}_{t} & =\left[\begin{array}{lllll}
X_{t-2} & X_{t-1} & X_{t} & X_{t+1} & X_{t+2}
\end{array}\right] \\
\boldsymbol{Y}_{t} & =\boldsymbol{A} \cdot \boldsymbol{X}_{t}^{\top}
\end{aligned}
$$

ただし $X_{t}$ は型締力 $(\mathrm{kN})$ であり, 成形機の 4 本のタイバーのうちの第 1 軸の 1 サイクル中の最大型締力センサー データの 4 倍とする．また， $\boldsymbol{Y}_{t}$ は平滑化された型締力である．次に，変化率 $C V_{t}$ を次式で定義する.

$$
C V_{t}=\left|\frac{Y_{t}-Y_{t-1}}{Y_{t-1}}\right| \times 10^{2}
$$




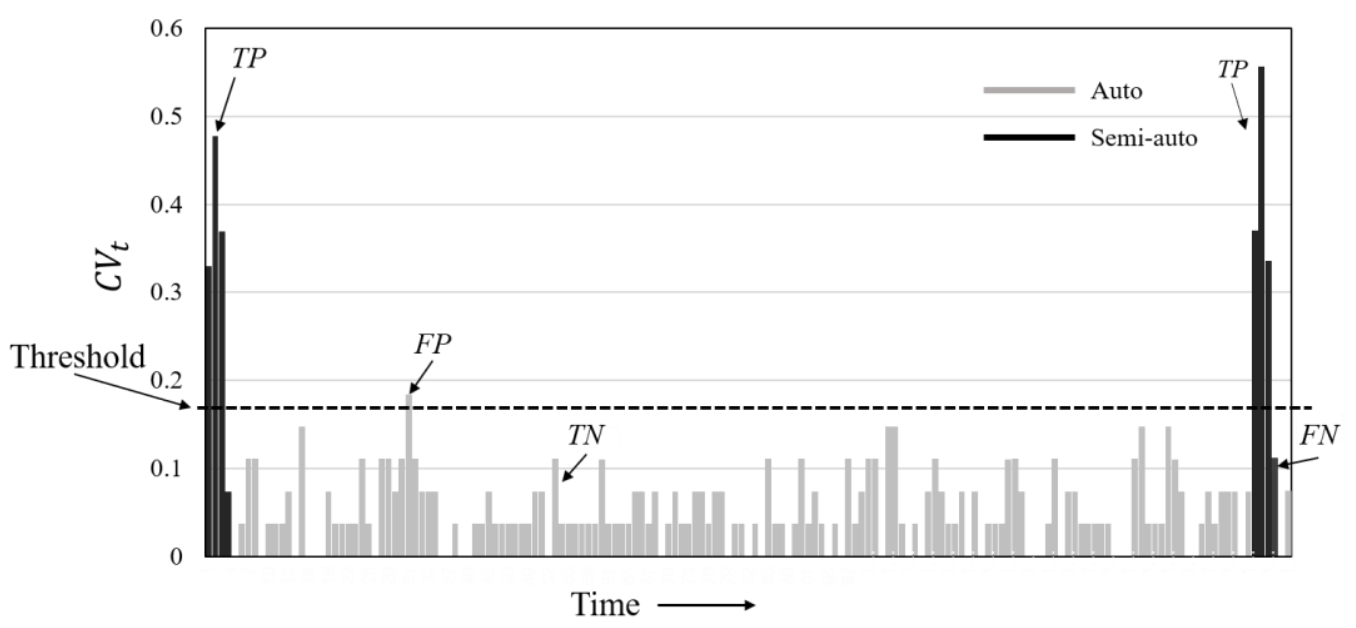

Fig.1 The time series of $C V_{t}$ by every single cycle. The dotted line (threshold) paralleled to horizontal-axis [taking an arbitrary position between maximum and minimum of $\left.C V_{t}\right]$ is able to classify the number of $T P, F P, F N$ and $T N$. Therefore the confusion matrix is created by this classification method.

Table 1 Confusion matrix by the operation mode.

\begin{tabular}{|c|c|c|c|}
\hline & \multicolumn{2}{|c|}{ Predicted operation mode } \\
\hline & & Semi-auto & Auto \\
\hline \multirow{2}{*}{$\begin{array}{c}\text { Actual } \\
\text { operation mode }\end{array}$} & Semi-auto & True positive $(\boldsymbol{T P})$ & False negative $(\boldsymbol{F N})$ \\
\hline & Auto & False positive $(\boldsymbol{F P})$ & True negative $(T N)$ \\
\hline
\end{tabular}

\section{$2 \cdot 2$ 運転モードにもとづく混同行列と闒值}

図 1 に, ある期間の半自動運転一全自動運転一半自動運転の変化率 $C V_{t}$ を示す. 横軸に平行な線で運転モードを 分離し， 2 項分類の混同行列を示したものである表 1 と対応するTP, FP, FN , TNを図に記入した. なお， 1 サ イクルごとの実際の運転モードは成形機内のメモリーにロギングされている.

分離線を変化させて式(5)による正解率 $A C$ を算出し, 最も高い正解率 $A C_{\max }$ を与える閾值を $T H$ とする.

$$
A C=\frac{T P+T N}{T P+F P+F N+T N}
$$

論文（長沼，橋本，2018）では分岐点精度（BEA）による閾值を用いた. BEA は異常検知器の性能評価および 比較の表現に適している（井手，杉山，2015）が，今回の事例のように異常という発生頻度の少ないデータを評 価する場合は，記録された全データを分類する混同行列に基づく正解率（Tan et al.,2014）がよいと考えた. なぜ なら，TPによって型締力が不安定な半自動モードにおける大きな変化率が検出できるからである.

\section{3. データの取得装置と取得方法}

データを取得するときに用いた装置は, 実際に生産を行っている電動射出成形機であり, 型締装置の故障が発 生した成形機を用いた，金型は取り数 8 個，3プレートタイプ, バルブゲート式ホットランナー，樹脂は PP, 成 形サイクルは約 5 秒である． A 社では成形機から出力することのできるセンサーデータのうち重要だと考えるデ 


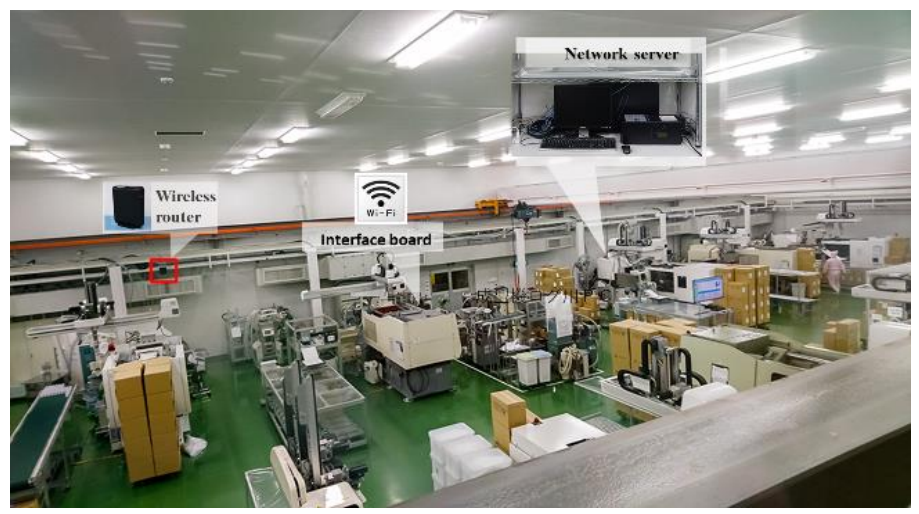

Fig. 2 This picture shows the inside of the production area.

The logging data from the machine is sent from an interface board via a router to the network server.

一タ項目を複数選択し，機械ごとに無線 LAN で工場内のネットワークアクセスポイントを経由して，生産中の 成形機の生産状態データをリアルタイムでネットワークサーバーコンピューターに蓄積している (図 2). 型締装 置が故障した成形機も他の成形機と同様にネットワークに接続されており，本研究で使ったデータは成形 1 サイ クルにおける計測日時，運転モード，最大型締力である.

\section{4. 計測結果と故障の状況}

計測を開始してから，型締装置の重大な故障が同一成形機の同一金型で 2 回起こった. 2017 年と 2018 年に 1 回ずつ起こったものであり，本研究ではこれらの故障のデータを用いる．またサイクルにおける型締力 $X_{t}$ は成 形機の 4 本のタイバーのうちの第 1 軸の 1 サイクル中の最大型締力センサーデータの 4 倍とする. 4 倍にした理 由は，標準の成形機の制御画面にも表示されるデータで，生産現場でも型締力の指標としてよく使われているか らである．また，最大型締力を採用した理由は金型が閉まる前後の動的な過程で発生するため変動幅が大きいた めである.

\section{$4 \cdot 1$ 故障事例 1 における故障状況とデータ}

故障の発生と復帰の状況を記す． 2017 年 1 月 15 日〜 3 月 19 日の 9 週間のデータを使用する. 第 6 週目の 2 月 26 日に成形機の型開閉時の異音と振動が大きくなり，生産続行が出来なくなり，作業員の判断により稼働を休止 した．その後，機械メーカーのサービス員が成形機を調査したところ，型締装置の駆動部であるボールネジに動 作不良があることがわかり，第 7 週目である 3 月 1 日に成形機のボールネジアッセンブリの交換が行われた．故 障したボールネジの一部の状態を図 3 に，場所を図 4 示寸。メーカーの解析結果からネジ部とナッ卜部の転動面 にフレーキングが発生しており，これが異音と振動の原因であった.

生産は 1 日 24 時間稼働にて週の初め（月曜日午前 8 時）に開始され，週末（土曜日または日曜日午前 8 時）に 終了するというパターンで行われているので，計測期間中の週ごとに型締力 $X_{t}$ の平均と最大值，最小值を運転モ 一ド（全自動，半自動）別に時系列で図 5 (a)，(b)にまとめた．第6 週目に故障が起こり，生産を中断したそその 後，第 7 週目に故障の復帰作業を行ったので，生産はなく，修理が完了した第 8 週目から生産が再開された。期 間全体では全自動モードで約 96 万サイクル，半自動モードで約 1700 サイクルのデータが得られた. 


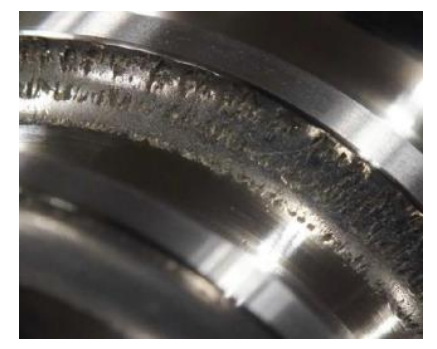

Fig.3 The ball screw from failure case 1 shows flaking. The raceway of ball screw peels off like scales because of fatigue.

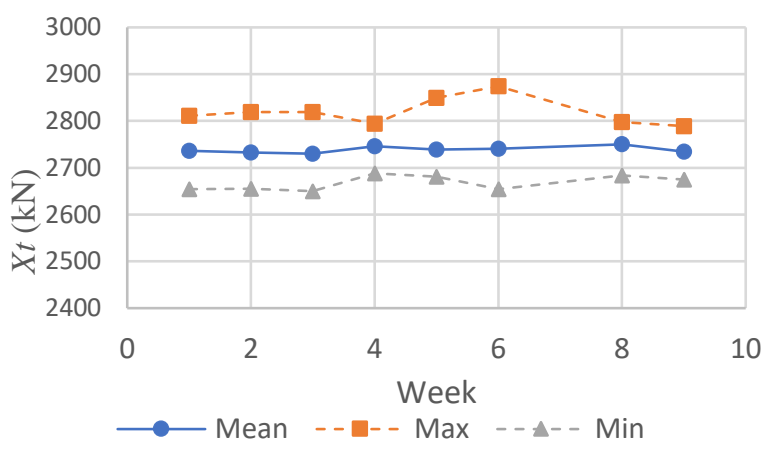

Fig.5(a) Mean, maximum and minimum clamping force in auto mode. Mean of clamping force is near $2700 \mathrm{kN}$ which is setting value and stable throughout the period.

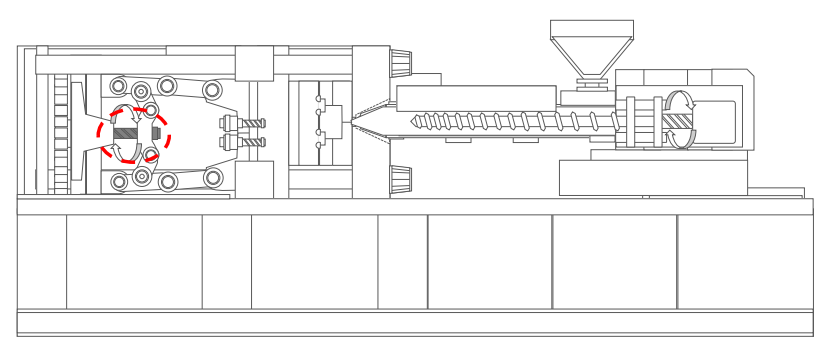

Fig.4 Red dotted circle in the injection molding machine indicates the machine failure part which is the ball screw.

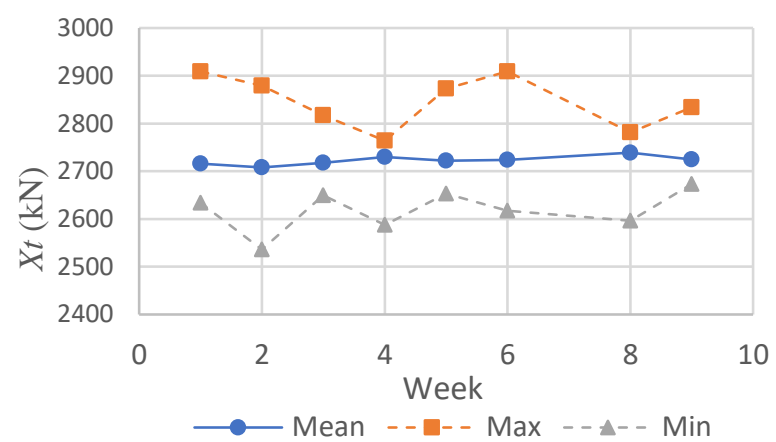

Fig.5(b) Mean, maximum and minimum clamping force in semi-auto mode. Mean of clamping force is stable throughout the period as well. All means of semi auto is lower than auto mode.

\section{4 - 2 故障事例 2 における故障状況とデータ}

故障の発生状況を記す。 2017 年 11 月 5 日〜2018 年 3 月 3 日の 16 週間のデータを使用する。第 16 週目の 3 月 3 日に事例 1 と同一の成形機で生産中に不規則に成形品不良（充填不足品）が発生し，生産続行が出来なくなり 作業員が稼働を休止した，その後，機械メーカーのサービス員が成形機を調査したところ，型締装置のレバーア 一ムに亀裂が入っていることが確認され (図 6 に状態, 図 7 に場所を示す), レバーアームアッセンブリが交換さ れ，復旧した。

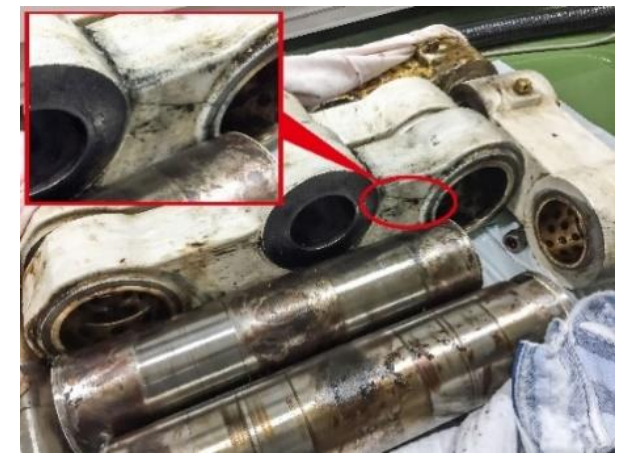

Fig.6 Red circle part and arrow indicates the toggle arm from failure case 2 has a crack.

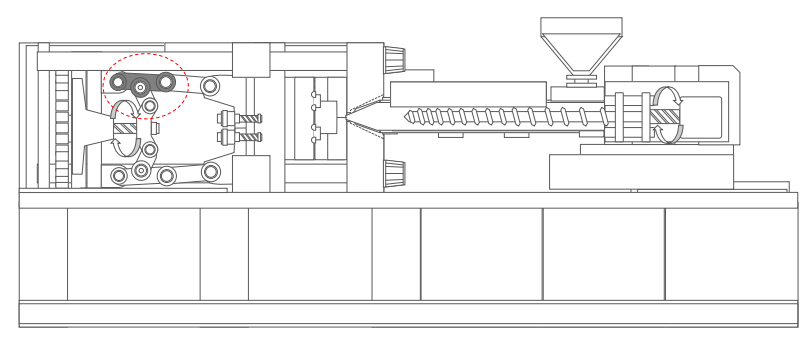

Fig.7 Red dotted circle in the injection molding machine indicates the machine failure part which is the toggle arm. 


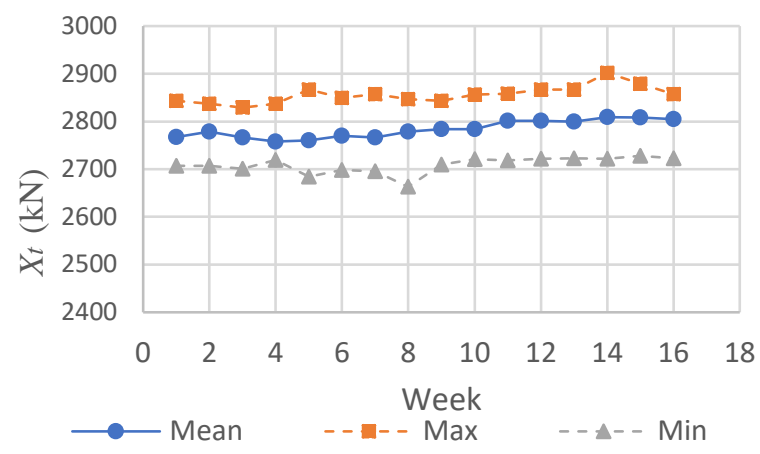

Fig.8(a) Mean, maximum and minimum clamping force in auto mode. Mean of clamping forces are near $2740 \mathrm{kN}$ which is setting value and stable throughout the period.

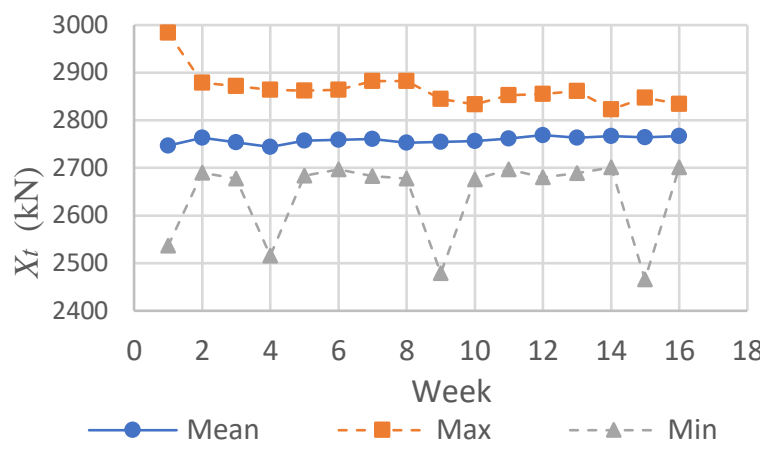

Fig.8(b) Mean, maximum and minimum clamping force in semi auto mode. The minimum clamping forces sometimes experience a large change even though the mean is stable. The reason for the large change occurring is uncertain.

故障前の 2017 年 11 月 5 日〜2018 年 3 月 3 日（16 週間）の最大型締力について, 2 サイクル毎のデータを取得 した．週ごとに型締力 $X_{t}$ を運転モード（全自動，半自動）別，時系列で図 8 (a)，(b)にまとめた．期間全体では全 自動モードで約 86 万サイクル，半自動モードで約 6200 サイクルのデータが得られた.

\section{5. 闒值を用いた異常検知に関する検証}

故障事例 1 の計測結果を使って混同行列を用いた閾値THによる異常検知の可能性について考察するそそし て，故障事例 1 の検知方法で，故障事例 2 でも同様に異常検知が可能かどうかを検証する.

\section{$5 \cdot 1$ 故障事例 1 を用いた異常検知方法の検討}

\section{$5 \cdot 1 \cdot 1$ 闒值THの算出と解釈}

期間中の週ごとのTHを表 2 に示す. 週ごとの全自動，半自動回数，その比率，THとその時の最大正解率 $A C_{\max }$ を示す．表 3 は第 6 週の状態を日別に表している. 図 9，10 は表 2，3 のTHを横軸に週あるいは日としてプロッ トした.

THは第 $1 \sim 5$ 週目までは $0.25 \sim 0.36$ 付近で安定的に推移していたが，故障が発生した第 6 週目は 0.76 に上昇 した（図 9)。そこで，第 6 週を日別に解析すると， 4 日目に突然 0.9 付近まで大きく上昇し，その後 0.5 付近ま で下がったが，8 日目に故障のため停止した（図 10)。このことより，故障の直前ではTHが大きな值をとること がわかる．また，4 日目に成形品に不具合（充填不足不良）が発生し，作業員が成形条件の変更などを試みたの で，半自動モードの割合が通常より多いことがわかる. そして修理後の第 8〜9 週目にはTHが 0.3 付近に戻って いる. 
Table 2 Quantitative summary of $T H$ for each week (failure case 1).

\begin{tabular}{|c|c|c|c|c|c|c|}
\hline \multicolumn{2}{|c|}{ Yr.2017 } & \multicolumn{2}{c|}{ Number of opreation mode } & Semi-auto ratio & \multicolumn{2}{c|}{ Maximum accuracy } \\
\hline Week & Week no. & (1)Auto & (2)Semi-auto & (2)/(1)+(2) $\times 100$ & $A C_{\max } \times 100$ & $T H$ \\
\hline $01 / 15 \sim 01 / 22$ & 1 & 121425 & 306 & 0.25 & 99.78 & 0.364 \\
$01 / 22 \sim 01 / 29$ & 2 & 122726 & 226 & 0.18 & 99.84 & 0.326 \\
$01 / 29 \sim 02 / 05$ & 3 & 121684 & 181 & 0.15 & 99.86 & 0.299 \\
$02 / 05 \sim 02 / 12$ & 4 & 125195 & 177 & 0.14 & 99.86 & 0.293 \\
$02 / 12 \sim 02 / 19$ & 5 & 117609 & 219 & 0.19 & 99.83 & 0.257 \\
$02 / 19 \sim 02 / 26$ & 6 & 108143 & 432 & 0.40 & 99.62 & 0.765 \\
$02 / 27 \sim 03 / 05$ & $7 *$ & & & & & \\
$03 / 05 \sim 03 / 12$ & 8 & 111280 & 95 & 0.09 & 99.93 & 0.291 \\
$03 / 12 \sim 03 / 19$ & 9 & 132029 & 100 & 0.08 & 99.94 & 0.326 \\
\hline
\end{tabular}

* The machine was down and a new ball screw assembly was installed in the clamping unit.

Table 3 Quantitative summary of $T H$ for each day in the week no.6 (failure case 1).

\begin{tabular}{|c|c|c|c|c|c|c|}
\hline \multicolumn{2}{|c|}{ Week no.6 } & \multicolumn{2}{c|}{ Number of opreation mode } & \multicolumn{2}{c|}{ Semi-auto ratio } & \multicolumn{2}{c|}{ Maximum accuracy } \\
\hline Day & Day no. & (1)Auto & (2)Semi-auto & (2)/(1)+(2) $\times 100$ & $A C_{\max } \times 100$ & $T H$ \\
\hline $02 / 19$ & 1 & 17810 & 42 & 0.24 & 99.80 & 0.257 \\
$02 / 20$ & 2 & 17764 & 25 & 0.14 & 99.88 & 0.294 \\
$02 / 21$ & 3 & 18144 & 20 & 0.11 & 99.91 & 0.258 \\
$02 / 22$ & 4 & 10303 & 170 & 1.62 & 98.58 & 0.858 \\
$02 / 23$ & 5 & 11692 & 51 & 0.43 & 99.56 & 0.877 \\
$02 / 24$ & 6 & 15486 & 74 & 0.48 & 99.54 & 0.691 \\
$02 / 25$ & 7 & 16945 & 50 & 0.29 & 99.71 & 0.510 \\
$02 / 26$ & 8 & 3720 & 82 & 2.16 & 97.86 & 0.613 \\
\hline
\end{tabular}

\section{$5 \cdot 1 \cdot 2$ 闒値 $T H$ と異常検知}

図 11 に第 6 週の 3 日目（2-21-2017）, 図 12 に第 6 週の 4 日目（2-22-2017）の半自動, 全自動モードの変化率 $C V_{t}$ とそれぞれに運転モード別の箱ひげ図に混同行列を重㸚合わせたものを示寸．これらは表 3 のTHで示すよう に，過去の安定していた状態とそこから大きく変化した 2 日間である．箱ひげ図はデータのバラツキを示すため に用いる．第 1 四分位点から第 3 四分位点までの高さに箱を描き，中央值で仕切り線を引く．また，上下の「ひ げ」は通常は最大值, 最小值を表すが，外れ值を考慮する場合は第 1 , 第 3 四分位点から箱の 1.5 倍の長さに引 き，それを超えるデータを外れ值とし，丸印でプロットする. 


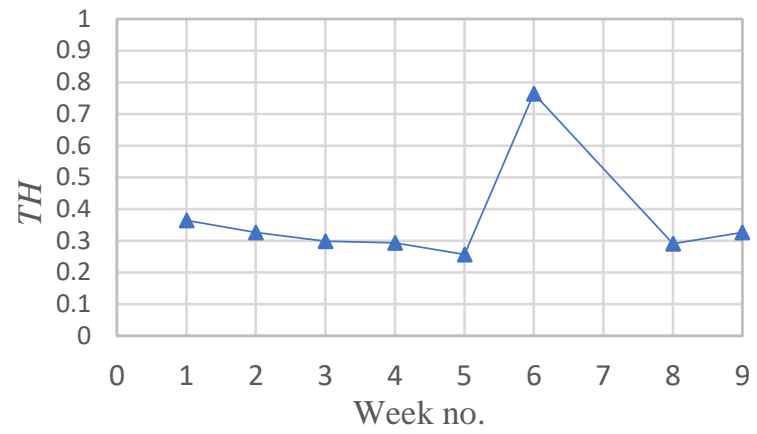

Fig.9 The change of threshold by each week. The failure happened with $T H$ in the 6th week, which represents an outlier from the other weeks. The clamping unit was repaired in the 7 th week.

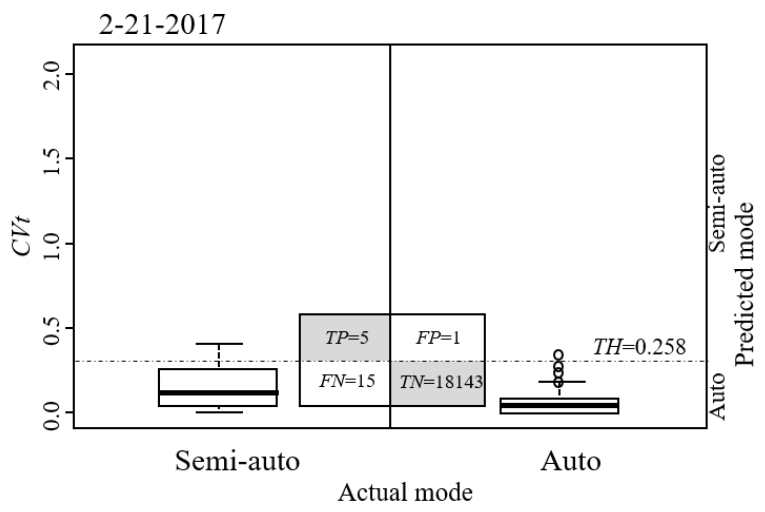

Fig.11 Boxplot of semi-auto and auto to $C V_{t}$ with confusion matrix of the day 2-21-2017. The most of $C V_{t}$ are less than 0.3 and there are a few outliers in auto mode. $C V_{t}$ in semi auto is less than 0.4 and there are no outliers.

Median in semi auto is higher than in auto.

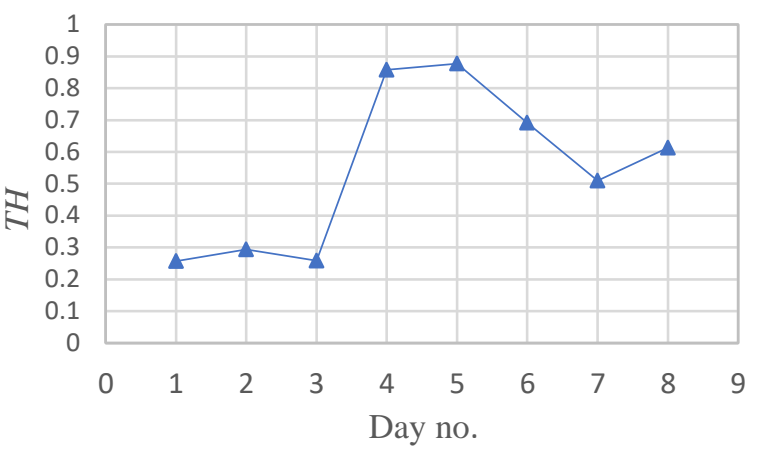

Fig.10 The change of threshold by each day in the 6th week. The first 3 days of $T H$ are lower value and stable. From the 4th day onwards, TH moves to a high value and is unstable throughout the rest of days.

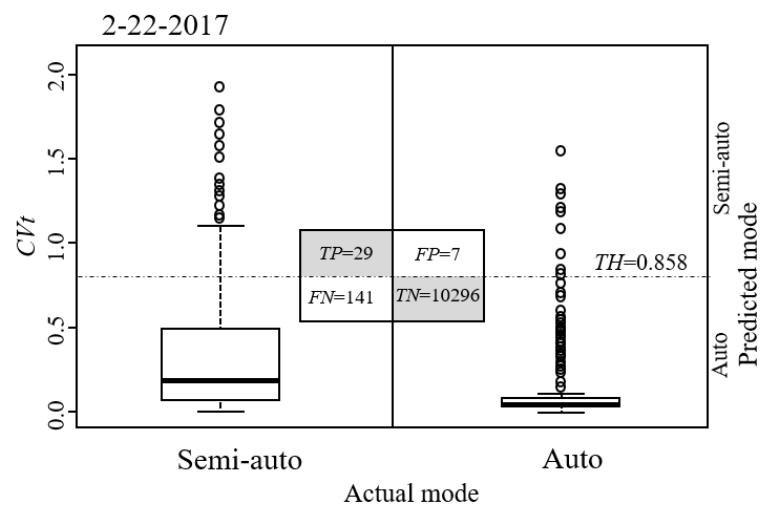

Fig.12 Boxplot of semi-auto and auto to $C V_{t}$ with confusion matrix of the day 2-22-2017. $C V_{t}$ in auto has a certain amount of outliers, with the maximum being approximately 1.6. The variance of $C V_{t}$ in semi auto is large in comparison to semi auto of the day 2-212017 and the maximum outlier in semi auto is approximately 2.0 .

まず，図 11 では全自動モードの数 18144 個 $(F P+T N)$ に対し，半自動モードは 20 個（TP + FN）であり， サイクル数のほとんどが全自動モードであることがわかる．その全自動モードの変化率 $C V_{t}$ を見ると，データの $75 \%$ (第 3 四分位) が 0 0.1 付近に集中している. 半自動モードと全自動モードの箱の大きさを比べるとデータ 数が圧倒的に少ない半自動のほうがバラツキが大きい. また，図 12 では, こちらも図 11 と同様に全自動モード 数がほとんどであり，バラツキも半自動モードのほうが大きい. しかし，どちらのモードも第 3 四分位から外れ 值の最大值までの距離が長くなっており，この区間でのデータのバラツキが非常に大きいことがわかる. 次に, 図 11 と 12 の相違点は図 11 のデータ分布が $0 \sim 0.4$ 付近と狭く, 図 12 のほうはデータ分布が $0 \sim 1.9$ 付近と広 く, 図 11 に比べ, 図 12 のほうがデータのバラツキは大きいと言える.

これらのデータの分布状態をもとに，THがどのように決まるか考察する. 式（5）より，ACを大きくするには $T P$ とTNの和を大きくするように $T H$ を定めることとなる. 全自動モードのTNに着目すると, $T P$ 《 TNなので, $T H$ は全自動モードの第 3 四分位（ $75 \%$ ）以上の $C V_{t}$ 值を取ることが予想される．具体的な計算方法は，本来は分 
離線のどこからどの向きに変化させるかは最終的な結果には影響しないが, 計算負荷の効率を考慮すると, 全自 動モードの最大值から, 半自動モードで得られたデータごとに分離線を下向きに変化させ, TPとTNの数をトレ 一ドオフしながら最大正解率 $A C_{\max }$ となるTHを見出す.このような方法で計算したところ, 図 11，12 より 2-212018 では TH = 0.258 であったが, 2-22-2018 ではTH = 0.858 と大きく変化し, その後の日々のデータは図 10 よりTH = 0.5 以上で推移し, 4 日後に型締装置の故障が発生し生産が出来なくなった.

すなわち, 成形機の運転時間を区切って, 寸べてのデータを用いて運転モードにもとづく混同行列を作成し， 半自動モードと全自動モードにおけるお互いの変化率 $C V_{t}$ のバラツキの状態よって, 型締装置の評価基準として のTHを決めることが出来た，そして，TH自身も変化率の指標であり，この数值が大きくなることはサイクル間 の型締力の変化が大きいことを表し，この数值の変化を監視すれば，異常検知が出来ると考える.

\section{$5 \cdot 2$ 故障事例 2 を用いた闘値 $T H$ による異常検知方法の検証}

故障事例 1 と同様の方法で週ごとに算出した $T H$ とその 5 週間の単純移動平均を図 13 に示す. 1 8 週目までは THが 0.21 付近で安定していたが, 9 11 週目は 0.3 付近にやや上昇, 12 週目には突然 0.63 と大きく上昇, その 後大きく上下動し, ついに 16 週目には型締装置が故障のために生産が出来なくなった. 移動平均の動きからも, 期間の前半は 0.2 付近で安定していたが, 後半からTHが上昇傾向にあることがわかる. この上昇傾向を示した後 に型締装置が故障していることから，この変化は装置の異常を検知していると考える.

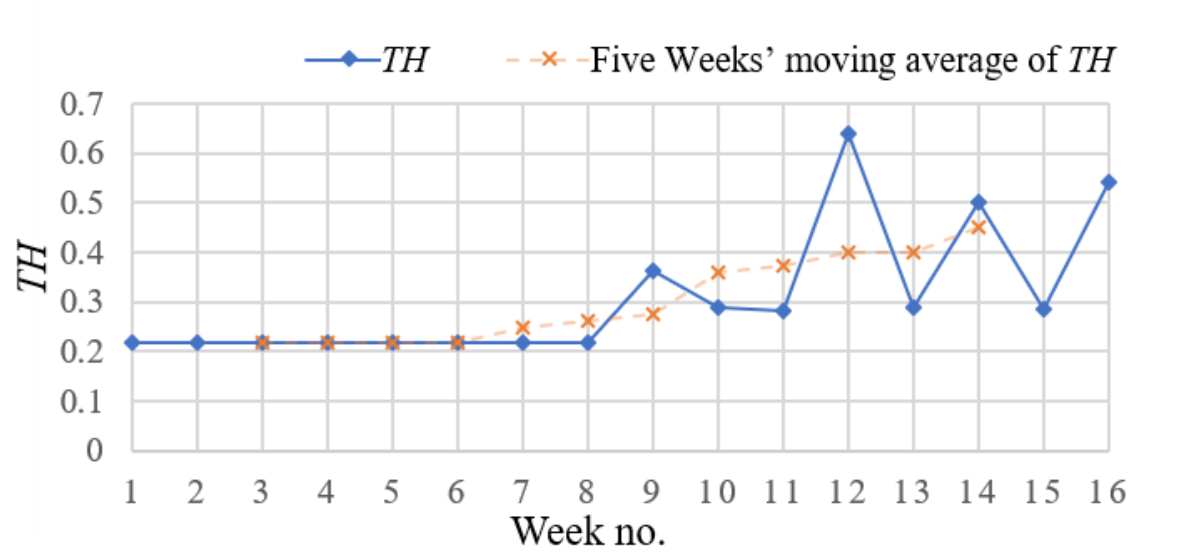

Fig.13 The change of TH by each week and five weeks' moving average. TH is stable from the 1st to the 8 th week and unstable after the 9th week. And the machine failure occurred at the 16th week.

\section{6. 結言}

$\mathrm{A}$ 社では生産中の成形機のログデータを取得するネットワークシステムが構築されている，その中の同一成形 機で生産中に型締装置の重大な故障が 2 例発生した. 成形機のログデータは A 社のネットワークサーバー内に保 管されており，これらのデータを用いて，筆者らがすでに提案した推定手法（長沼，橋本，2018）で考案した 2 つの運転モードにおける混同行列とその閾值により具体的な異常検知を行うための手法を検討した. 寸なわち本 研究において, 混同行列を使った型締力変化率 $C V_{t}$ に対し閾值 $T H$ にる算出方法を提案し試みた. その結果, 闇 值THの数值に着目寸ると故障事例 1 では生産不能になる 4 日前から, また, 故障事例 2 でも同じく数週間前か ら上昇傾向が観察され，それが故障の前兆であることを示すことが出来た.

THは最大正解率を求めるための閾值ではあるが, 本論文ではその閾値自身の変化を 1 日, または週単位で監視 することにより, 異常検知が出来ることを明らかにした，実際の運用方法としては，たとえば安定していると思 われるTHを正常值として記録・記憶しておき, 判定のための基準値として用いる (高橋, 2003). そして, 前日 または前の週ごとに閾值THを算出し，基準值に対する上限值を設け，それを超えたら装置の検查や保全を行え ば，今回の事例のような大きな故障を未然に防げる可能性がある. 


\section{文 献}

内閣府，日本経済 2016-2017 (2017), p.73.

井手剛, 杉山将, 異常検知と変化検知 (2015), pp.10-11,講談社.

Jähne, B., Digital image processing (2005), pp.306-312, Springer Science \& Business Media.

JIS B 8650，プラスチック加工機械一用語， 日本規格協会 (2006).

経済産業省，2017 年版ものづくり白書 (2017), p.60.

長沼恒雄, 橋本浩一, 射出成形機の型締力変化からの運転モードの推定, 日本機械学会論文集, Vol.84, No.857(2018),

DOI:10.1299/transjsme.17-00417.

日本電気株式会社, 住友重機械と NEC 産業機械の故障予兆に AI を活用, 日本電気株式会社ホームページ, available from $<$ https://jpn.nec.com/press/201712/20171213_01:html>, (参照日 2018 年 4 月 21 日).

沖本竜義, 計量時系列分析 (2016), pp.4-5, 朝倉書店.

高橋幸雄，機械・装置及びプラントの異常検出（二），日本マリンエンジニアリング学会誌, Vol.38, No.11 (2003), pp.22-26.

Tan, P., Steinbach, M. and Kumar, V., Introduction to data mining (2014), pp.294-298, Pearson Education Limited.

\section{References}

Cabinet office government of Japan, Japanese economy 2016-2017 (2017), p.73 (in Japanese).

Ide, T. and Sugiyama, M., Anomaly detection and change detection (2015), pp.10-11, Kodansha (in Japanese).

Jähne, B., Digital image processing (2005), pp.306-312, Springer Science \& Business Media.

JIS B 8650, Plastics molding machinery Vocabulary, Japanese standards association (2006) (in Japanese).

Ministry of economy, trade and industry government of Japan, White paper on manufacturing industries (2017), p.60 (in Japanese).

Naganuma, T. and Hashimoto, K., Estimation of operation mode from the clamping force variation of injection molding machine, Transaction of the JSME (in Japanese), Vol.84, No.857 (2018), DOI:10.1299/transjsme.17-00417.

NEC corporation, Sumitomo heavy industries and NEC apply AI to the sign of production machinery failure, NEC corporation web page, available from < https://jpn.nec.com/press/201712/20171213_01:html>, (accessed on 21 April,2018), (in Japanese).

Okimoto, T., Time series analysis for economic and financial data (2016), pp.4-5, Asakura publishing Co., Ltd. (in Japanese).

Takahashi, Y., Detection of abnormalities of machinery and plant systems (2), Journal of the JIME, Vol.38, No.11 (2003), pp.2226 (in Japanese).

Tan, P., Steinbach, M. and Kumar, V., Introduction to data mining (2014), pp.294-298, Pearson Education Limited. 